\title{
Determinants of Voluntary Tax Compliance (THE CASE CATEGORY A AND B TAXPAYERS IN DIRE DAWA ADMINISTRATION)
}

\author{
Netsanet Shiferaw \\ Lecturer, Department of Accounting and Finance, College of Business and Economics, \\ Dire Dawa University, Ethiopia \\ Biniam Tesfaye (MBA) \\ Lecturer, Department of Management, College of Business and Economics, \\ Dire Dawa University, Ethiopia
}

\begin{abstract}
Improved tax compliance boosts the revenues available for supporting public services without increasing the current tax burden on compliant tax payers. The voluntary compliance behavior of the taxpayers is determined by various factors and identifying these factors and treating them accordingly should be the central premises of any tax system in order to maintain voluntary compliance at satisfactory levels. The study investigate the five key determinants of voluntary tax compliance from existing literature and previous studies which include Demographic factors, Economic factors, Institutional factors, Social factors and Individual factors. The main objective of the study is to examine the determinants of voluntary tax compliance behavior of category A and B tax payers in Case of Dire Dawa City Administration. To achieve the objective, the authors use Pragmatics or mixed research approach. To this end, the researchers used both primary and secondary data. The target populations of the study are category " $A$ " and "B" tax payers in Dire Dawa City Administration. A sample of 366 category " $A$ " and " $B$ " tax payers is taken by using multi stage sampling procedure. The findings from the regression analysis indicate that, compliance is significantly affected by nine determinant factors which consist of: Age, Education, Tax knowledge, Financial Constraints, Absence of Fairness, Role of the Tax Authority, complexity of Tax System, Absence of Tax Audits and Government Spending. This study also evidenced that, other variables such as Gender, Sales turn over, Religion, Penalties, Type of organization and Tax Rate were not significant determinants of tax compliance id Dire Dawa City Administration.
\end{abstract}

Keywords: Tax Compliance, Category A\&B Tax Payers and order logit regression model

DOI: $10.7176 /$ RJFA/11-13-05

Publication date:July $31^{\text {st }} 2020$

\section{CHAPTER ONE INTRODUCTION}

\subsection{Background of the study}

Tax, Peace and Justice are the three corner stone for the development of any country and existence of any government. Governments in developing countries face great challenges in mobilizing tax revenues, which result in a gap between what they could collect and what they actually collect. Thus they hardly cover their expenditure using tax revenue as they receive a very low amount of revenue from taxation. This is because the domestic tax bases in most African countries including Ethiopia are undermined by widespread tax avoidance and evasion which are the main significant contributors to tax gaps (IMF, 2011; ITD, 2010).

As stated by (Fjeldstad 2006), this is also due to the fact that local government tax administrations in most local government authorities in Africa are often inefficient and not able to properly account for revenues collected. Mascagni et al (2014), as cited by Kanbiro (2018) now the governments of developing countries, particularly sub-Sharan Africa countries collect much lower proportions of their GDPs of tax revenue which is less than average is $16 \%$ even if they have high capacity to raise tax revenue to promote their economic development. Similarly, Swarnathilaka and Kevin (2017), disclose that the government of Sri Lanka was able to collect only 514.1 billion against a target of 605.3 billion during the period of 2014/15 financial year. Likewise, the United Kingdom estimates loss in tax revenues to be \$21 billion per year, Greece estimates showed loss in tax revenues to be $\$ 30$ billion per year. In developing countries, overall tax revenues loss due to tax evasion is estimated to $\$ 285$ billion per year. According to World Bank 2013 report, tax revenue in lower-income countries, account for only about 10 to 14 percent of GDP, one-third less than in middle income countries and far below the 20 - 30 percent of GDP reached in high income countries. Ameyaw and Dzaka (2016)

Like other developing countries, Ethiopia faces hurdles in raising revenue to the required level in order to scale up the development endeavors. The existing level of revenue collection remains low compared to the revenue generating potential of the economy and the total resource demand for government expenditure commitment. The main reason of this low revenue collection performance is due to tax noncompliance attitude of tax payers and poor tax administration. According to tax to GDP ratio which was collected in GTP I is $13.3 \%$ even though the government has been planned to raise $15.3 \%$ tax-to-GDP. Hence, the revenue is expected to 
increase from the current level of 13.3 percent of GDP in 2014/15 to 17.2 percent by $2019 / 20$ in GTP II. Total government revenue (domestic revenue), which stood at 199.6 Billion Birr by the end of 2014/15, is projected to reach Birr 620.6 billion by the end of 2019/20. Out of the total government revenue, Birr 603.3 billion is expected to be generated from domestic sources (tax and non-tax) of which Birr 542.8 billion is projected to be raised through tax revenue. For taxation to be effective in achieving both short and long term goals in any economy, the level of tax compliance must be improved. Ethiopia's ratio of tax revenue to gross domestic product (GDP) is still well short of the international average. Currently, the ratio of tax revenue to GDP in Ethiopia is less than 11 per cent which is generally considered below the threshold i.e $16 \%$, while in many African countries the average ratio exceeds 20 per cent (Kenya 23\% and Tanzania 17\%).

According to Akalu (2016), tax non-compliance affects revenue collection and the ability of the government to achieve its fiscal and social goals. Improved tax compliance amplifies the revenues available for supporting public services without increasing the current tax burden on compliant taxpayers. Rizal et al (2016) among the undesirable impacts of noncompliance, they reduce the national revenue significantly and thus encouraging a hidden economy in which inequities in the economy would be derived. Judging from the negative impacts of noncompliance, the paper attempts to provide some measures in order to reduce noncompliance rates in Dire Dawa city administration.

\subsection{Statement of the problem}

Desta (2010) stated that any strategy to increase tax compliance should begin with a theory of why people cheat on their taxes. Understanding the factors that determine the compliance behavior of taxpayers is not only important for one city but also for Ethiopia as a whole in order to designing appropriate strategies to deal with non-compliers so that they can gradually develop the desired behavior of voluntary compliance. Akalu (2016)

Based on the Pareto (20/80 rule) principle $80 \%$ of tax is collected from $20 \%$ of higher tax payers. This is the main reason why many tax authorities currently establish especial offices for treating large tax payers separately. The contribution of tax revenue collected from category C to GDP is significantly small when compared with that of category A and B tax payers. So, to improve the tax revenue collection category A and B Tax payers have to be the area of focus for Tax authorities. Thus, tax gap is related with Voluntary compliance (the tendency of not over stating payment and understating income) of which the greater percentage is contributed by those who have the lion share (category A and B tax payers) in the revenue mobilization of the country. Thus, indentifying these factors particularly political factors related with tax compliance behavior of category A and B Tax payers, the main contributors of tax revenue of the country, is very crucial and urgent.

According to Amhara national regional state, the level of compliance for category A and category B tax payers is only $9.95 \%, 8.94 \%$ and $11 \%$ during 2005, 2006 and 2007 E.C, respectively. These indicate that the level of tax compliance in the region during the last 3 years was low, so it must be improved for efficient tax administration. Dinku and Alamirew (2018) Similarly data from Dire Dawa Revenue Authority the percentage of actual revenue over budget revenue from direct tax, indirect tax, other tax and municipal revenue is decline from year to year. For instance in year 2010, 2014, 2015, 2016 and 2017 percentage of collection was 125.21\%, $107.63 \%, 104.42 \%, 89.84 \%$ and $70.80 \%$ respectively. This data clearly show that the revenue which is collected by the authority is decline from one period to another period. Likewise, according to the information obtained from Dire Dawa City Tax Authority as cited by Lemessa (2007), only about $60 \%$ of the business communities which are subjected to tax are paying their tax obligation regardless of the existing powerful tax proclamation. This clearly shows that, in order to addressing the issue of voluntary compliance participatory and holistic approach is more important instead of relying on legal enforcement.

what is more importantly draw the attention of researchers of this study is that the Ethiopian societies diversity in terms of the social, cultural and psychological, ethical, demographical political outlook and geographical factors which intern affects the attitudinal make up of the tax payers and closely related with tax compliance behaviors of tax payers are not still considered by most Ethiopian scholars conducting research in this area before this time. At the same time Dire Dawa, where the prevailing regional diversity believed to bring different results from and as important as the outcomes gained from the previous researches conducted in different regions of the country unquestionably will come up with an important solution for the tax compliance problems specifically related to the region and can be an eye opener study used as a point of reference for any issue related to tax compliance of the region. Hence, there is a clear need for more empirical research on the factors that affect tax compliance, since a better understanding of these factors can yield strategies that improve compliance. Thus, to fill all the above stated knowledge gap, conducting research on this issue is too imperative

\subsection{Objectives of the Study}

\subsubsection{General objective}

The major objective of this study is to examine the determinants of voluntary tax compliance behavior of category A and B tax payers in Case of Dire Dawa City Administration 


\subsubsection{Specific objectives}

In line with above general objective, the specific objectives of the study are:

The specific objectives of this study are:

$>$ To identify the determinants of the tax compliance of taxpayers.

$>$ To examine the nature of relationship between taxpayers' compliance and the respective determinants.

$>$ To identify the most significant factor of the tax compliance.

\subsection{Research Hypotheses}

$\mathrm{H} 1$ : There is a positive relation between age and tax compliance.

$\mathrm{H} 2$ : Female tax payers are more compliant than male taxpayer.

$\mathrm{H} 3$ : There is a positive relation between education and tax compliance.

H4: Higher income level of taxpayers is negatively associated with tax compliance.

H5: knowledge about tax is positively correlated with voluntary compliance

H6: Personal financial constraint is negatively correlated with tax compliance.

H7: Awareness of penalty and Offences is positively correlated with tax compliance.

H8: Perception of absence of fairness and equity of tax system is negatively associated with tax compliance.

H9: Type of organization does not affect the level of compliance.

H10: Role of the tax authority is positively correlated with tax compliance.

H11: Complexity of tax system has a negative relationship with tax compliance.

H12: Religious tax payers are more tax compliant than those who are not.

H13: The perception on tax rate is negatively related with tax voluntary compliance attitude

H14: There is a negative relationship between absence of audited and tax compliance.

$\mathrm{H}$ 15: Positive perception of government spending is positively correlated with tax compliance.

\section{CHAPTER TWO LITERATURE REVIEW}

\subsection{Definition of taxation}

Tax is defined (Bhatia, 2003) as a compulsory contribution (levy) by an economic unit to a government without expectation of direct and equivalent return (quid pro quo) from the government for the contribution made.similarly , Parameswaren (2005) define tax as a compulsory levy imposed by an organization or Government on its member citizens, for the sole purpose ofproviding common goods and services for the benefit of all members.Generally, governments levy taxes for multiple of purposes, but mainly to raise funds in order to cover public expenditures and on the other hand to properly allocate resources.

\subsection{Definition of Tax Compliance}

Swarnathilaka and Kevin (2017), tax compliance is defined as the ability and willingness of taxpayers to comply with tax laws, declare the correct income in each year and pays the right amount of taxes on time. Likewise Song and Yarbrough (1978), it is the taxpayers' ability and willingness to comply with tax laws which are determined by ethics, legal environment and other situational factors at a particular time and place. Kirchler (2007) defined as the willingness of individuals to report all incomes and payment of all taxes by fulfilling the provisions of laws, regulations and court judgments. Moreover different authors defined tax compliance as it is a person's act of filing their tax returns, declaring all taxable income accurately, and disbursing all payable taxes within the stipulated period without having to wait for follow-up actions from the authority.

\subsection{Factors of tax compliance}

\subsubsection{Demographic Factors}

Age; Some researchers argued that aging taxpayers tend to be more compliant than the younger taxpayers since younger taxpayers are more risk seeking and less sensitive to penalties. For instance chung and trivedi (2003) argued that positive relation between age and tax compliance. On other hand Akalu (2016) found that there is a negative relationship between age and compliance level. However, there have been a studies including Manchilot (2018) found no relationship between age and compliance

Gender; According to the research made by Hasseldine and Hite (2003) sometimes female taxpayers are male compliant than their male counterparts. Whereas other studies found that male taxpayers were more compliant than female. Manchilot (2018), gender has no significant impact on compliance attitude of taxpayers.

Education; Most of the studies including Ameyaw and Dzaka (2016) and Daba (2017) found that education level is directly linked to a likelihood of compliance i.e. positive relationship between educational level and taxpayer compliance.

Income; The studies of Allingham and Sandmo (1972) revealed that higher income level attracts higher compliance on the other hand Johns and Slemrod (2008) argued that increment in income levels resulting increase in tax evasion behavior. Kanbiro (2018) found that income does not have significant influence on tax 
voluntary compliance attitude.

Religion; According to Kirchgässner (2003), religiosity, measured as church attendance and the perceived degree of religiosity may also play a role in tax morale and voluntary compliance as those who take their religion to heart may find attempts at non compliance as been "unrighteous". The finding of Torgler and Schaltegger (2007) also support this view as their results suggested a positive correlation between church attendance/religiosity and tax morale. Blumenthal, Christian and Slemrod (2001) reporting findings from a field experiment, identified the impact of moral persuasion on voluntary income tax compliance.

\subsubsection{Individual factor}

Tax knowledge; Daba (2017) and Lemessa (2007) stated that there is a positive relation between tax knowledge and compliance, while Manchilot (2018), Tadesse and Goitom (2014), and Kanbiro (2018), found that tax knowledge does not significantly correlated with compliance behavior of tax payer.

Personal financial constraints; According to Daba (2017) and Tadesse and Goitom (2014), personal financial constraints is the major determinant of voluntary compliance. As stated by Mohani, 2001, financial problem is negatively correlated with the tax payer voluntary compliance when compared to people in less financial distress. Awareness of penalties and Offences; According to Ameyaw and Dzaka (2016), awareness about penalties and Offences has a positive relation with compliance. If the taxpayers are aware of the offences they are committing when evading tax and the consequences of being non-compliant taxpayers, they might reduce their tendency to evade tax. While Tadesse and Goitom (2014) found that awareness of penalties and Offences were not significantly correlated with tax compliance

\subsubsection{Social Factors}

Perceptions of absence of equity or fairness; Desta (2010), Lemessa (2007) and Daba (2017) determined that fairness or equity is the most significant factor influencing tax payer compliance. Jackson and Milliron (1986) argued that as one of the main principles of the taxation system, Perceptions of equity or fairness have a positive influence on the compliance level of the tax payers. Whereas the studies made by Kanbiro (2018), Akalu (2016) and Tadesse and Goitom (2014) found that equity or fairness doesn't have any impact on compliance level.

\subsubsection{Institutional Factors}

Role of the tax authority; According to Desta (2010) and Lemessa (2007), the role of the tax authority in minimizing the tax gap and increasing voluntary compliance is clearly very important. The study of Richardson (2008) and Manchilot (2018) also suggested that the role of a government has a significant positive impact on determining attitudes toward tax. Tadesse and Goitom (2014) and Kanbiro (2018), found that Role of the tax authority doesn't have any impact on compliance level.

Complexity of tax system; According to Swarnathilaka and Kevin (2017) and Manchilot (2018) simplifying tax administration is important because it can facilitate efficient and enhanced administration and reduce noncompliance level. So Simplicity of tax system increases the compliance level i.e. Simplicity of tax system positively related with tax compliance. Similarly, complexity of tax system makes compliance difficult, requiring taxpayers to devote excessive time to preparing and filing their returns. Akalu (2016) found that there is no any relation between compliance and complexity of tax.

\subsubsection{Economic Factors}

Tax Rate; Akalu (2016) and Ameyaw and Dzaka (2016) found that high tax rates leads to lower level of tax compliance. Opposite to the view Kirchler, Hoelzl \& Wahl, (2008) found there is positive relationship between tax compliance and tax rate thus as tax rate increase, the compliance level also increase. Swarnathilaka and Kevin (2017) found that tax rates have not significant effect on tax compliance decision.

Absence of Tax audits; The study made Daba (2017) and Tadesse and Goitom (2014) revealed that tax audit is one of the most effective policies to protect tax compliance. Swarnathilaka and Kevin (2017) claimed that audits have a positive impact to increase voluntary compliance. An increase in tax audits automatically minimizes the rate at which taxpayers noncompliance behavior i.e. tax audits can change compliance behavior from negative to positive.

Perceptions of government spending; Tadesse and Goitom (2014) and Kanbiro (2018), found that Perception of government spending were not significantly correlated with tax compliance. 


\subsection{Conceptual Framework}

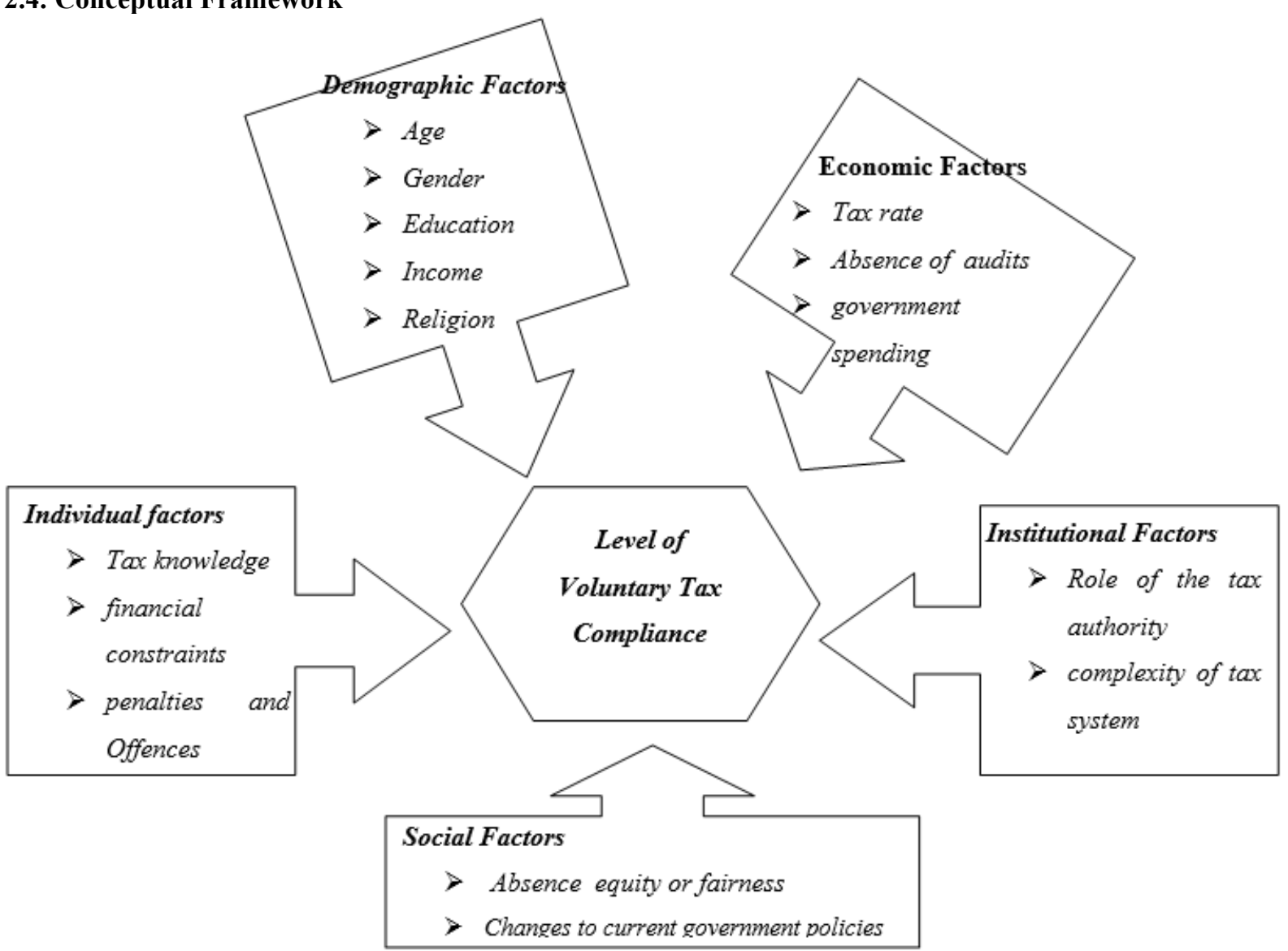

Source: - Adopted From Kanbiro (2018) with some modification

\section{CHAPTER THREE RESEARCH METHODOLOGY}

\subsection{Research Design}

The researcher used the triangular approach: which is a combination of both qualitative and quantitative data.

\subsection{Philosophical Paradigms}

The current study applies Pragmatics research approach.

\subsection{Type and Methods of Data Collection}

To undertake the study the researcher used both primary and secondary data. The primary collected from two sources; from the taxpayers and from tax authority officials. The data that collected from the tax payers e through questionnaire and the data that collected from the tax officials through questionnaire and interview. Secondary data also collected through document analysis from published and unpublished sources.

\subsection{Population and Target Population of the Study}

\begin{tabular}{|c|c|c|c|c|c|c|c|c|c|c|}
\hline \multirow[b]{2}{*}{ CATEGORY } & \multicolumn{9}{|c|}{ Kebele } & \multirow[b]{2}{*}{ TOTAL } \\
\hline & 01 & 02 & 03 & 04 & 05 & 06 & 07 & 08 & 09 & \\
\hline$A$ & 117 & 872 & 455 & 267 & 118 & 256 & 337 & 230 & 283 & 2935 \\
\hline$B$ & 42 & 461 & 203 & 162 & 89 & 140 & 151 & 104 & 15 & 1367 \\
\hline$C$ & 1318 & 5118 & 1048 & 1822 & 625 & 1401 & 2222 & 1369 & 2707 & 17630 \\
\hline TOTAL & 1477 & 6451 & 1706 & 2251 & 832 & 1797 & 2710 & 1703 & 3005 & 21932 \\
\hline
\end{tabular}

Table 1: Total Number of Business Income Tax Payers in Dire Dawa

> The target population of the study will tax authority and category "A" and "B" tax payers of the city.

\subsection{Sampling Techniques and Sample Size Determination}

The researchers use Yamane (1967) formula to calculate sample size. It is assumed that the sample would have $95 \%$ reliability about population and a sampling error $5 \%$. 


$$
\begin{aligned}
& n=\frac{\mathrm{N}}{1+\mathrm{N}(\mathrm{e})^{2}} \\
& ={ }^{\frac{4,302}{1+4,302(0.05)^{2}}} \\
& =366
\end{aligned}
$$

Where,

$\mathrm{N}=$ study population

$\mathrm{n}=$ sample size and

$\mathrm{e}=$ error margin

$>$ Accordingly the following formula used to determine sample from each kebele:

$\mathrm{ni}=\mathrm{n} *-\frac{\mathrm{Ni}}{N} i=1,2,3$,

Where,

$\mathrm{ni}=$ sample size of the $\mathrm{i}^{\text {th }}$ stratum

$\mathrm{n}=$ sample size

$\mathrm{Ni}=$ population size of the $\mathrm{i}^{\text {th }}$ stratum and

$\mathrm{N}=$ represents the population size.

Finally, a sample size of 366 from each category, i.e. category "A" (250) and category "B" (116) allocate proportionally for each kebele depending on the number of business income tax payer in each Kebele

\subsubsection{Model specification}

Taxpayers are assumed to be compliant if they reporting their correct taxable income to tax authority, their willingness to comply with directives and regulations of tax authorities and the intention neither to evade nor avoid tax paid. Based on this score, taxpayers were categorized into three levels of compliance as: tax payers are more compliant, the tax payer is moderately compliant, and the tax payer is low compliant. Therefore this ranking merits the use of either ordered logit/probit model to analyze those responses. But, for this study ordered logit model is adopted.

\subsubsection{Rationality for model selection}

An ordered logit model for an ordinal response $\mathrm{Yi}$ with $\mathrm{C}$ categories is defined by a set of $\mathrm{C}-1$ equations where the cumulative probabilities $g c i=\operatorname{Pr}(Y i \leq y c \mid x i)$ are related to a linear predictor $\beta^{\prime} \times i=\beta 0+\beta 1 \times 1 i+\beta 2 \times 2 i+\ldots$ through the logit function:

$\operatorname{logit}(\mathrm{gci})=\log (\mathrm{gci} /-1(\mathrm{gci}=)) \alpha \mathrm{c}-\beta^{\prime} \mathrm{xi}, \mathrm{c}=1,2, \ldots, \mathrm{C}-1$

The parameters $\alpha \mathrm{c}$, called thresholds or cut points, are in increasing order $(\alpha 1<\alpha 2<\ldots<\alpha \mathrm{C}-1)$. It is not possible to simultaneously estimate the overall intercept $\beta 0$ and all the $\mathrm{C}-1$ thresholds: in fact, adding an arbitrary constant to the overall intercept $\beta 0$ can be counteracted by adding the same constant to each threshold $\alpha c$. This identification problem is usually solved by either omitting the overall constant from the linear predictor (i.e. $\beta 0=$ 0 ) or fixing the first threshold to zero (i.e. $\alpha 1=0$ ).

The vector of the slopes $\beta$ is not indexed by the category index c, thus the effects of the covariates are constant across response categories. This feature is called the parallel regression assumption: indeed, plotting logit(g ci) against a covariate yields $\mathrm{C}-1$ parallel lines (or parallel curves in case of a non-linear specification ghuu From equation (1), the cumulative probability for category $\mathrm{c}$ is

$\operatorname{gci}=\exp \left(\alpha c-\beta^{\prime} x i\right) /\left(1+\exp \left(\alpha c-\beta^{\prime} x i\right)\right)=1 /\left(1+\exp \left(-\alpha c+\beta^{\prime} x i\right)\right)$.

An ordinal response $\mathrm{Yi}$ with $\mathrm{C}$ categories can be represented as an underlying continuous response $\mathrm{Yi}^{*}$ with a set of $\mathrm{C}-1$ thresholds $\alpha \mathrm{c}^{*}$ such that $\mathrm{Yi}=\mathrm{yc}$ if and only if $\alpha \mathrm{c}-1^{*}<\mathrm{Yi}^{*} \leq \alpha \mathrm{c}^{*}$. It follows that a cumulative model for an ordinal response, such as the ordered logit model (1), is equivalent to a system composed of a set of thresholds $\alpha c^{*}$ and a linear regression model for an underlying continuous response:

$\mathrm{Yi}^{*}=(\beta *)^{\prime} \mathrm{xi}+\mathrm{ei}^{*}$

where ei* is an error with mean zero and standard deviation $\sigma \mathrm{e}^{*}$. The relationship $\operatorname{Pr}(\mathrm{Yi} \leq \mathrm{yc})=\operatorname{Pr}\left(\mathrm{Yi}^{*} \leq \alpha \mathrm{c}^{*}\right)$ implies that the linear model (3) is equivalent to the cumulative model $1(\mathrm{gci})=\alpha \mathrm{c}-\beta^{\prime} \mathrm{xi}$, where the link function $1(\cdot)$ is the inverse of the distribution function of the error ei*.

In the empirical model $\mathrm{Yi}^{*}$, represents levels of compliance as: tax payers are more compliant-y1, the tax payer is moderately compliant-y2, and the tax payer is low compliant-y3,

$\mathrm{Xi}$, represents explanatory variables, Age, Gender, Education, Income, Tax knowledge, Personal financial constraints, Awareness of penalties and Offences, Perceptions absence of equity or fairness, types of organization, Role of the tax authority, Religion, Tax rate, Tax audits, complexity of tax system, Perceptions of government spending, $\beta *$ s represent coefficients of explanatory variables. Unit of measurement, description of variables and Expected signs/hypotheses are described by the table below: 


\begin{tabular}{|c|c|c|c|c|c|c|}
\hline No & Factors & Variables & Symbols & $\begin{array}{l}\text { Unit of } \\
\text { measurement }\end{array}$ & $\begin{array}{l}\text { Description } \quad \text { of } \\
\text { Variables }\end{array}$ & $\begin{array}{l}\text { Expected } \\
\text { signs/hypotheses }\end{array}$ \\
\hline \multicolumn{7}{|c|}{ Dependent variable } \\
\hline 1 & & $\begin{array}{l}\text { Tax } \\
\text { compliance }\end{array}$ & TCOMP & Ordinal & $\begin{array}{lr}\text { Willingness } & \text { to } \\
\text { comply } & \text { with } \\
\text { directives } & \text { and } \\
\text { regulations of tax } \\
\text { authorities and the } \\
\text { intention not to evade } \\
\text { tax paid. }\end{array}$ & \\
\hline \multicolumn{7}{|c|}{ Explanatory variables } \\
\hline 2 & \multirow{5}{*}{ 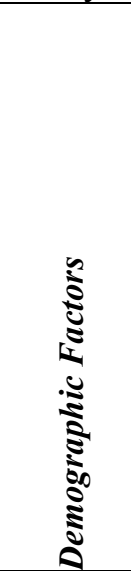 } & Age & AGE & Ordinal & $\begin{array}{l}\text { The length of time } \\
\text { that a person lived. }\end{array}$ & $\begin{array}{l}+ \text { ( Aged tax payers, } \\
\text { higher compliance) }\end{array}$ \\
\hline 3 & & Gender & GEN & Binary & $\begin{array}{l}\text { The state of being } \\
\text { male or female. }\end{array}$ & $\begin{array}{l}+ \text { ( Females, more } \\
\text { compliance })\end{array}$ \\
\hline 4 & & Education & EDU & Ordinal & $\begin{array}{l}\text { The level of literacy } \\
\text { by the tax payer. }\end{array}$ & $\begin{array}{l}+(\text { Educated tax } \\
\text { payers, } \\
\text { compliance })\end{array}$ \\
\hline \multirow[t]{2}{*}{5} & & Income & INCO & Continuous & $\begin{array}{l}\text { Company profit in a } \\
\text { particular period of } \\
\text { time. }\end{array}$ & $\begin{array}{lr}\text { - ( Higher income } \\
\text { level, } \\
\text { compliance })\end{array}$ \\
\hline & & Religion & RELG & Binary & $\begin{array}{l}\text { set of beliefs and } \\
\text { practices generally } \\
\text { agreed upon by a } \\
\text { group of people. }\end{array}$ & $\begin{array}{lr}+(\text { strict } & \text { religion } \\
\text { followers, } & \text { high } \\
\text { compliance }) & \end{array}$ \\
\hline 6 & \multirow{3}{*}{ 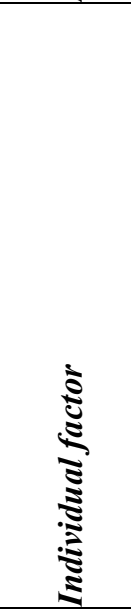 } & $\begin{array}{l}\text { Tax } \\
\text { knowledge }\end{array}$ & TKNOW & Nominal & $\begin{array}{l}\text { Understand and cope } \\
\text { with the } \\
\text { administrative and } \\
\text { legal requirements i.e. } \\
\text { tax policies, } \\
\text { procedures, rules and } \\
\text { regulations. }\end{array}$ & $\begin{array}{l}+\quad \text { (High } \\
\text { knowledge, } \\
\text { compliance })\end{array}$ \\
\hline 7 & & $\begin{array}{l}\text { Personal } \\
\text { Financial } \\
\text { Constraints }\end{array}$ & FINACONS & Ordinal & $\begin{array}{l}\text { Any factor that } \\
\text { restricts the amount or } \\
\text { quality of investment } \\
\text { options. }\end{array}$ & $\begin{array}{lr}- & \text { (Financial } \\
\text { constraint, } & \text { low } \\
\text { compliance) } & \end{array}$ \\
\hline 8 & & $\begin{array}{l}\text { Awareness of } \\
\text { Penalties and } \\
\text { Offences }\end{array}$ & PENAL & Continuous & $\begin{array}{l}\text { Related with paying } \\
\text { taxes because of fear } \\
\text { of being caught and } \\
\text { penalized. }\end{array}$ & $\begin{array}{l}+ \text { (High penalty, high } \\
\text { compliance })\end{array}$ \\
\hline 9 & 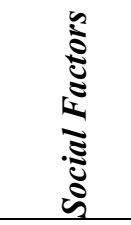 & $\begin{array}{ll}\text { Absence } & \text { of } \\
\text { Fairness } & \text { or } \\
\text { Equity } & \end{array}$ & EQUIFAIR & Continuous & $\begin{array}{l}\text { Treat equal people in } \\
\text { equal circumstances } \\
\text { in different way. }\end{array}$ & $\begin{array}{lr}\text { - (Absence } & \text { of } \\
\text { fairness }, & \text { less } \\
\text { compliance) } & \end{array}$ \\
\hline 11 & \multirow{3}{*}{ 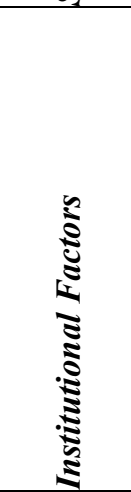 } & $\begin{array}{l}\text { Role of the } \\
\text { Tax } \\
\text { Authority }\end{array}$ & TAUTO & Nominal & $\begin{array}{l}\text { Maintain an } \\
\text { aggressive attitude } \\
\text { with respect to the } \\
\text { correctness of the } \\
\text { taxpayers' actions. }\end{array}$ & $\begin{array}{l}+ \text { ( High efficiency } \\
\text { of tax authority, } \\
\text { higher compliance) }\end{array}$ \\
\hline \multirow[t]{2}{*}{12} & & $\begin{array}{l}\text { complexity of } \\
\text { Tax System }\end{array}$ & TSIMP & Nominal & $\begin{array}{l}\text { Easily understandable } \\
\text { and designed on the } \\
\text { basis of appropriate } \\
\text { set of principles. }\end{array}$ & $\begin{array}{lr}\text { - } \quad(\text { complexity } & \text { of } \\
\text { system, } & \text { less } \\
\text { compliance }) & \end{array}$ \\
\hline & & $\begin{array}{l}\text { Type of } \\
\text { organization }\end{array}$ & TYPEORG & Nominal & $\begin{array}{l}0=\text { Manufacturing; } \\
\text { 1= Merchandizing; } 3= \\
\text { Service }\end{array}$ & Not significant \\
\hline
\end{tabular}




\begin{tabular}{|c|c|c|c|c|c|c|}
\hline No & Factors & Variables & Symbols & Unit & Description & Expected \\
\hline 13 & \multirow{3}{*}{ 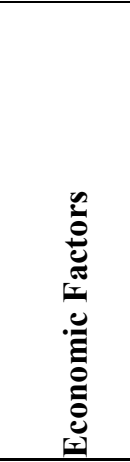 } & Tax Rate & TRATE & Nominal & $\begin{array}{l}\text { The percentage at } \\
\text { which a business is } \\
\text { taxed. }\end{array}$ & $\begin{array}{ll}\text { - } & \text { High tax } \\
\text { rate, low } & \\
\text { compliance) }\end{array}$ \\
\hline 14 & & $\begin{array}{l}\text { Absence of } \\
\text { tax Audits }\end{array}$ & TAUDI & Nominal & $\begin{array}{l}\text { The continuous } \\
\text { inspection or } \\
\text { examination of the tax } \\
\text { authority. }\end{array}$ & $\begin{array}{l}-\quad \text { (absence } \\
\text { inspection }, \\
\text { compliance) }\end{array}$ \\
\hline 15 & & $\begin{array}{l}\text { Perceptions } \\
\text { of } \\
\text { Government } \\
\text { Spending } \\
\end{array}$ & GOVSPEND & Nominal & $\begin{array}{l}\text { The proper } \\
\text { utilizations of taxes } \\
\text { which are collected } \\
\text { by the government. }\end{array}$ & $\begin{array}{l}+ \text { (Good perception } \\
\text { of gov't spending } \\
\text { high compliance) }\end{array}$ \\
\hline
\end{tabular}

Table 2: Description of variables

CHAPTER 4 DATA PRESENTATION, INTERPRTATION AND ANALYSIS

The major objective of this study is to examine the determinants of voluntary tax compliance behavior of category A and B tax payers in Case of Dire Dawa City Administration. Out of a total number of 366 questionnaires distributed, the results are made based on 321 questionnaires collected from the taxpayers and interviews made with taxpayers' representatives and tax consultants. This made the return rate around $87.70 \%$, indicates good response rate. In order to analyze the data both descriptive and econometric methods were used.

\subsection{General Background of Respondents}

The descriptive result indicate that, the age distribution of the respondent was 18-30 (32.71\%), 31-40 (57.94\%), and 41 and above $(9.35 \%)$ years of old. This implies that majority of respondents were at the range of $31-40$ $(57.94 \%)$ years of age. There were more male respondents 198 (61.68\%) than female respondents $123(38.3 \%)$. Regarding level of education, $3(0.93 \%)$ of the respondents had diploma, $279(86.92 \%)$ of respondent had Bachelor Degree and the rest $39(12.15 \%)$ of respondents have Master Degree. Therefore, the implication is the majority of business taxpayers have a good academic background. The result of the study shows that 156 $(48.60 \%)$ of the respondents are engaged in manufacturing, $72(22.43 \%)$ are merchandising and the remaining 93 $(28.97 \%)$ are service sectors. This shows that the majority of higher tax payers in administration are engaged in manufacturing businesses. With regards to Sales Turnover 120 (37.38\%) earn annual turnover income between $500,000-1,000,000$ and the remaining $201(62.62 \%)$ were earn above 100000 . Consequently majority of high tax payer in Administrations were classified under category A business income Tax payers.

\subsection{Regression Results}

The collected data were checked for errors and completeness; ordered logit regression model was used to analyze determinants of tax compliance. The result on Table 4.1 shows that the likelihood ratio chi-square of 50.88 with a p-value of 0.0000 tells us that the model as a whole is statistically significant. The Variance Inflation Factor (VIF) is a popular measure of multicollinearity among the independent variables. As 'a rule of thumb', if the mean VIF of variables exceeds 10 , that variable is said to be highly collinear and it can be concluded that multicollinearity is a problem. As shown in the table 4.1, the average value of VIF of variables of this study was 1.66 which is less than 10 . Therefore, the results of the VIF values for the variables confirmed that there is no serious problem of multicollinearity. 
Table 4. 6 Variance Inflation Factor (VIF)

\begin{tabular}{|l|l|l|}
\hline Variable & $\boldsymbol{V I F}$ & $\mathbf{I} \boldsymbol{V I F}$ \\
\hline Perception of Absence of tax Audits & 2.28 & 0.439433 \\
\hline Type of organization1 & 2.20 & 0.455565 \\
\hline Perception of Government Spending & 2.10 & 0.476649 \\
\hline Perception of Role of the Tax Authority & 2.05 & 0.486930 \\
\hline Tax knowledge & 1.79 & 0.558193 \\
\hline Education & 1.78 & 0.560557 \\
\hline Type of organization2 & 1.72 & 0.580989 \\
\hline Perception of Absence of Fairness & 1.62 & 0.618371 \\
\hline Perception of complexity of Tax System & 1.56 & 0.641933 \\
\hline Perception of Penalties & 1.52 & 0.658327 \\
\hline Perception of Financial Constraints & 1.52 & 0.659355 \\
\hline Perception of Religion & 1.47 & 0.680175 \\
\hline Age & 1.38 & 0.725932 \\
\hline Perception of Tax Rate & 1.23 & 0.815549 \\
\hline Income & 1.22 & 0.821022 \\
\hline Gender & 1.18 & 0.850734 \\
\hline Mean VIF & 1.66 & \\
\hline
\end{tabular}

Table 4.2: Ordered Logistic Regression Results with marginal effect

Ordered logistic regression

$$
\begin{array}{llc}
\text { Number of obs } & = & 315 \\
\text { Wald chi2(16) } & = & 50.88 \\
\text { Prob }>\text { chi2 } & = & 0.0000 \\
\text { Pseudo R2 } & = & 0.1325
\end{array}
$$

\begin{tabular}{|c|c|c|c|c|c|c|c|c|c|c|}
\hline No & Sprit of tax law & Coef & $\begin{array}{l}\text { Robust } \\
\text { Std. Err. }\end{array}$ & $\mathrm{z}$ & $\mathrm{P}>|\mathrm{z}|$ & & $\begin{array}{l}\text { Mfx }=d y / d x \\
\text { p outcome } \\
\text { (2) }\end{array}$ & $\begin{array}{l}\text { Mfx }=\text { dy/dx p } \\
\text { outcome (3) }\end{array}$ & $\begin{array}{l}\text { Mfx }=\text { dy } / d x \quad p \\
\text { outcome (4) }\end{array}$ & $\begin{array}{l}\text { Mfx=dy/dx } \\
\text { p outcome } \\
\text { (5) }\end{array}$ \\
\hline 1 & Age & .7597883 & .2206503 & 3.44 & 0.001 & $* * *$ & -.0384002 & -.0316652 & $\begin{array}{l}-.0677948 \\
\end{array}$ & .1378601 \\
\hline 2 & Gender & -.1057243 & .2840168 & -0.37 & 0.710 & & .0053434 & .0044062 & .0094336 & -.0191832 \\
\hline 3 & Education & -1.216339 & .6474247 & -1.88 & 0.060 & * & .0614745 & .0506925 & .1085321 & -.2206991 \\
\hline 4 & Sales turn over & -.1914879 & .1675443 & -1.14 & 0.253 & & .0096779 & .0079805 & .0170862 & -.0347446 \\
\hline 5 & $\begin{array}{l}\text { Perception of } \\
\text { Religion }\end{array}$ & -.1446773 & .2424092 & -0.60 & 0.551 & & .0073121 & .0060296 & .0129093 & -.026251 \\
\hline 6 & Tax knowledge & 1.617207 & .419806 & 3.85 & 0.000 & $* * *$ & -.0817346 & -.0673993 & -.1443009 & .2934348 \\
\hline 7 & $\begin{array}{l}\text { Perception of } \\
\text { Financial Constraints }\end{array}$ & -.3931741 & .2010587 & -1.96 & 0.051 & ** & .0198713 & .0163861 & .0350823 & -.0713397 \\
\hline 8 & $\begin{array}{l}\text { Perception of } \\
\text { Penalties }\end{array}$ & .2605225 & .2217283 & 1.17 & 0.240 & & -.013167 & $\begin{array}{l}-.0108576 \\
\end{array}$ & -.023246 & .0472706 \\
\hline 9 & $\begin{array}{l}\text { Perception of } \\
\text { Absence of Fairness }\end{array}$ & $\begin{array}{l}.7082671 \\
\end{array}$ & .2945956 & -2.40 & 0.016 & $* *$ & .0357963 & .029518 & .0631976 & -.1285119 \\
\hline 10 & $\begin{array}{l}\text { Perception of Role } \\
\text { of the Tax Authority }\end{array}$ & .539652 & .2445357 & 2.21 & 0.027 & *** & -.0272743 & -.0224907 & -.0481523 & .0979174 \\
\hline 11 & $\begin{array}{l}\text { Perception of } \\
\text { complexity of Tax } \\
\text { System }\end{array}$ & -.6151628 & .152528 & -4.03 & 0.000 & $* * *$ & .0310907 & .0256377 & .0548901 & -.1116185 \\
\hline \multirow[t]{2}{*}{12} & $\begin{array}{l}\text { Type of } \\
\text { organization1 }\end{array}$ & .2964538 & .3136746 & 0.95 & 0.345 & & -.0149268 & $\begin{array}{l}-.0123029 \\
\end{array}$ & -.0267407 & .0539705 \\
\hline & $\begin{array}{l}\text { Type of } \\
\text { organization2 }\end{array}$ & .2049681 & .2852029 & 0.72 & 0.472 & & -.0098678 & -.0082264 & -.0201661 & .0382602 \\
\hline 13 & $\begin{array}{l}\text { Perception of Tax } \\
\text { Rate }\end{array}$ & .213806 & .1694241 & 1.26 & 0.207 & & -.0108059 & $\begin{array}{l}.0089107 \\
\end{array}$ & -.0190776 & .0387941 \\
\hline 14 & $\begin{array}{l}\text { Perception of } \\
\text { Absence of tax } \\
\text { Audits }\end{array}$ & -1.086008 & .3369308 & -3.22 & 0.001 & $*$ & .0548875 & .0452608 & .0969029 & -.1970512 \\
\hline 15 & $\begin{array}{l}\text { Perception of } \\
\text { Government } \\
\text { Spending }\end{array}$ & 1.12151 & .3395116 & 3.30 & 0.001 & $*$ & -.0566818 & -.0467404 & -.1000707 & .2034929 \\
\hline
\end{tabular}

Log pseudolikelihood $=-291.35518$

Note: $* * *$ and $* * *$ indicate statistically significant at $10 \%, 5 \%$ and $1 \%$ probability level, respectively.

Source: Own survey and model result, 2017

\section{Hypothesis 1: Age and compliance}

As it was hypothesized, this variable was found positive and statistically significant (at $1 \%$ significance level) relationship between age and tax compliance $(\beta=.7597883)$ with $p$ value of 0.001 . The study reviled that aged taxpayers has positive compliance attitude than younger tax payers. This result indicates that as the number of 
the live hood increase, the compliance level also increases. This could be explained by the fact that younger taxpayers are new to the tax system, they are risk taker and they have been shown to have less well developed sense of moral obligation to pay tax. In addition to this, the marginal effect of .1378601 dealings that the probability of individuals on their tax compliance was increased by $13.78 \%$, when the age is increase by one by having the other factors being constant. This result supports the finding of Rizal \& Fariq A(2011)

\section{Hypothesis 2: Gender and compliance}

With regard to gender, although findings from other studies were not conclusive and a concrete solution is still being debated, this study found that gender of the respondents has no impact on level compliance, as it is shown on the regression table 4.2 above, the coefficient of gender is -.1057243 which is negative and the $p$ value of 0.710 which is not statistically significant. The result of the study is not consistent with the hypothesis set in the study i.e. null hypothesis is rejected. This result supports the finding of Ezana (2018).

\section{Hypothesis 3: Education and compliance}

The result of this study showed that educational level of tax payers was negatively and significantly determine tax compliance at $10 \%$ significant level $(\beta=-1.216339)$ with $\mathrm{p}$ value 0.060 . The study found that education has negative and significant effect on the tax payer's level of compliance. The finding of this study agrees that when the level of education becomes increase, the compliance level become decrease i.e. leading to higher tax evasion. Furthermore, there have been contradictory empirical evidences on the effect of education on the level of tax compliance. Marginal effect -.2206991 indicate as education status of an individual was improved by one level, the tax compliance behavior of the individual decrease by $22.07 \%$, other factors being constant.

\section{Hypothesis 4: income and compliance}

The income of the respondents also has no impact on their compliance level, as it is shown on the regression table 4.1 above, the coefficient of income is -.1914879 which is negative and the $p$ value of 0.253 which is not statistically significant. The negative coefficient of income implies that there is an inverse relationship between the level of income and compliance level. Thus the hypothesis of the study is rejected.

\section{Hypothesis 5: religion and compliance}

It is assumed that religion encourage individuals to act according to tax law. If a tax payer thinks that this is conflicting with his religious beliefs, he will not be willing to pay taxes, at least not be willing to accept and will be act of resistance. Tax payer with good religious view is expected to be more compliant then a tax payer with poor religious view. However, the result of the regression analysis indicate that Religious view is insignificant factor by having coefficient of -.1446773 and $p$ value of 0.551 to determine the level of compliance. Thus the hypothesis of the study is rejected.

\section{Hypothesis 6: tax knowledge and tax compliance}

The level of tax knowledge is an important factor that contributes to compliance level. Therefore, respondents were asked different questions to assess the level of their knowledge of tax rules and how they are complying with tax requirements. The results shown in the regression Table 4.1 above describes that, the knowledge of respondents have a positive coefficient 1.617207 and the $\mathrm{P}$ value of 0.000 , which means that, tax knowledge plays an important role on tax compliance. Accordingly, the result of this study, tax knowledge has positive and significant relationship with tax compliance. These findings show that high tax knowledge would increase tax compliance behavior. Hence, hypothesis is accepted. In addition to this, the marginal effect of .2934348 dealings that the probability of individuals on their tax compliance was increased by $29.34 \%$, when tax knowledge is improved by one having the other factors being constant. The studies made by Inasius (2018), Olugoke and Obazee (2016), Rizal \& Fariq A(2011), Mukhlis et.al (2015) also support the result of this study.

\section{Hypothesis 7: financial constraints and compliance}

With regard to financial constraints, the researchers had put the hypothesis which is "financial constraints has a significant negative effect on taxpayers' compliance". As shown in the regression table 4.1 above, the predictor variable financial constraints has a coefficient of -.3931741 which is negative and the $p$ value of 0.051 which is significant at 5\% significance level. The negative coefficient -.3931741 implies that the more the respondents face financial constraints are less likely to comply with tax. These results provide evidence those tax payers who have crucial financial constraints would tend to be less compliant (negative association). The marginal effect of.0713397 indicates that one unit increase in financial constraint; it decreases the probability of compliance behavior by $7.13 \%$. The result from the regression analysis is consistent with the research conclusions made by Mohani, (2001).

\section{Hypothesis 8: Penalties/offences and compliance}

As one can understand from the table 4.1 above, fines and penalties have the coefficient of .2605225 and the $\mathrm{P}$ value of 0.240 which indicates, the fines and penalties is not significant factor to determine the level of compliance. Thus, the result of the study found that the effect of the penalty rate of increase on voluntary tax compliance was minimal \& insignificant. The interview result reviled that one that pay tax by fearing of the penalty is not voluntary compliance. If fines are too high, the tax system would be perceived as unjust and unfair and taxpayers would use any possibility to legally avoid their taxes. In most countries, fines are relative to the 
evaded tax. Therefore, they argued that, developing the culture of voluntary compliance in society through incentives and awards to the one who paid the tax on time is more important than force them by fines and penalty to comply. Olugoke and Obazee (2016), tax knowledge has a higher tendency to promote tax compliance than tax penalty. Then this result rejects the established hypothesis. From the above regression table, by having the marginal effect a unit increase in tax knowledge would lead to 0.30 increases in tax compliance while a unit increase in tax penalty would lead to 0.13 increases in tax compliance.

\section{Hypothesis 9: Absence of Fairness/Equity and compliance}

The results of this study indicate that fairness is the strongest factor determining the level of compliance level.nIn this study as it is shown in the regression table 4.1 above, absence of fairness is one of the predictor variables and which have a coefficient of -.7082671 and the $\mathrm{P}$ value of 0.016 , which means that, the taxpayers who perceived the tax system as unfair, it is more likely to reduce the motivation and tax compliance of current taxpayers. If the tax payers believed that there is absence of fairness in the tax system of the country, the level of compliance become decline. The most important point in many countries of the world is that whether citizens are taxed according to the ability to pay principle or not. If the society feel as that the country tax system is fair and they are paid based on the ability to pay, it will have positive impact for the level of compliance. When the relationship between tax equity \& voluntary tax compliance is examined, the most important reason for the negative reaction against taxes is availability of unfair tax. Tax equity is that citizens with a similar ability to pay taxes have to pay the same or similar amounts; citizens with a greater ability have to pay more, and with lower ability have to pay less. This equity is expressed as; horizontal equity (taxpayers in the same income brackets should pay the same amount of taxes) and vertical equity (taxes paid increase with the increase in tax base). This result is consistent with Inasius (2018), Mukhlis et.al (2015). Thus, hypothesis is accepted and well supported. The marginal effect of -.1285119 indicates a probability of perception about unfair system increase by one unit will decreases the probability of compliance behavior by $12.85 \%$.

\section{Hypothesis 10: role of government and compliance}

The variable was found to have positive and significant relationship with tax compliance at $5 \%$ significance level $\beta=.539652$ and $p$ value of 0.027 . Thus the hypothesis is accepted. The marginal effect of .0979174 indicate that when the role of the tax authority increased, the probability of tax compliance behavior of the individual increased by $9.79 \%$. To increase the compliance level of the tax payer, the tax administration provide a way by Creating awareness, Commitment to enforce the tax law, Giving training and empowering tax payers, Feedback on issues, Documentation, Customers handling, Ability to detect and Taking measure on perpetrators investigate evasions. Thus, Strength of the tax authority was expected to have positive impact on tax compliance level the tax payers. The study made by Richardson (2008) and Manchilot (2018) also suggest that there is direct relationship between role of government and compliance.

\section{Hypothesis 11: complexity of tax system and compliance}

The finding of this study with regard to Complexity of the tax system $((\beta=-.6151628)$ has negative and $p$ value of 0.000 significant relationship with tax compliance. The finding of the study confirm the hypothesis thus, hypothesis is accepted. Accordingly under the canons of taxation one of the principle is the tax system should be simple and easy to complete but it may not equally simple for all taxpayers. According to Kanbiro (2018), simplifying the tax return will encourage tax payers to complete the tax return on their own rather than employing a tax agent and thus reducing compliance. Consequently, one of the best technique to increase compliance is simplifying tax system in the country. According to Swarnathilaka and Kevin (2017), Denmark, Canada and New Zealand are the leading countries that have introduced simplified tax returns by reducing the number of pages to facilitate and increase voluntary compliance among taxpayers. Therefore, simplifying tax returns and administration system is the best way to ensure tax compliance. The complexity of tax laws contributes to the tendency of underreported (noncompliance) tax. It can be concluded that, tax laws \& legislation should be clear \& simple, shouldn't be overhauled frequently. The marginal effect of -.1116185 indicates that if the tax payers feel that the tax system is complex, the probability of tax compliance behavior of the individual decrease by $11.16 \%$.

\section{Hypothesis 12: type of organization and compliance}

With regard to type of organization, the researcher had putted the hypothesis which is type of organization have insignificant effect on the taxpayers' compliance. As shown in the regression table 4.1 above, the predictor variable (type of organization) has the $\mathrm{p}$ value of 0.345 and .472 which is not statistically significant.

\section{Hypothesis 13. Tax rate and tax compliance}

As the ordered logit regression model result indicates, tax rate is not important factor that determines tax compliance level of the tax payers. From the regression results of table 4.1 coefficient result $(\beta=.213806)$ and $p$ value of 0.207 show that the rate of tax has insignificant factor to determine the level compliance, which implies that we reject the Hypothesis stating that there is a negative significant relationship between tax rates and tax compliance. In addition the interview result reviled that, when the compliance cost such as salary of accountants, fees to tax consultants \& tax representatives, cash register machine $\&$ its maintenance or renewal cost, is high it 
also negatively affect the level of compliance. The result of the study consistent with Inasius (2018)

\section{Hypothesis 14: Absence of tax audit and compliance}

The finding of this study show that the coefficient of the independent variable regard to absence of audit ( $\beta=-$ 1.086008 ) and $p$ value of 0.001 has negative and significant relationship with tax compliance. Thus, hypothesis is accepted and concludes there is a significant negative relationship between probability of being audited and tax compliance decision. The study finds that the absence of tax audit strengthen the incentive to report less income. This indicates that there is inverse relationship with absence of tax audit and level of compliance. The result of some studies is consistent the finding of this study; audits have a positive impact on the level of compliance of tax payers Inasius (2018), Prince et.al (2014). The marginal effect of -.1970512 indicate that The probability of absence of audited increase by one unit, decrease level of compliance by $19.70 \%$

The level of tax audit can be determined by two elements: one is how many taxpayers are selected for audit and the second is how much intensive the audit is. The tax payers were asked the number of times they have been audited the last 10 years. Majority of the respondent reply that they are not known they are audited by the tax authority. The reaming large number of respondent stated that they are audited by tax authority after 5 years. Therefore it is crucial to make continuous tax audit practice by revenue Authority hence the level of tax compliance status becomes positively changed. This means that the compliance rate rises if the tendency of being tax-audited is high. If the tax payers are informed that their fillings will be closely examined, there is a tendency for the tax payers behaviour to change in response to an increased probability of been tax audited. The interview result exposed that the tax administrators of Dire Dawa city administration has limited capacity to investigate the records and low audit coverage

\section{Hypothesis 15: government spending and compliance}

As one can understand from the table 4.1 above, government spending have the coefficient of 1.12151 and the $\mathrm{P}$ value of 0.001 which indicates, the government spending have significant positive effects on taxpayers' compliance at $5 \%$ significance level. Thus wise spending of the governmental unit will have positive impact to increase the voluntary compliance of the tax payer. If taxpayers perceive that the government is spending too much on something they consider unnecessary, they will feel betrayed and attempt to evade taxes. These imply that taxpayers are more compliant when they are satisfied with the services provided by the government. According to Inasius( 2018), Taxpayers, particularly those paying high amounts of taxes, are sensitive to the direction of government spending and their attitudes also depend on the perceived use of the collected money by the government unit. This finding also consistent with the findings of Prince et.al (2014).

\section{Measures taken by tax authority to motivate Tax payers to pay tax}

The interview result reviled that, there is no regular training and updates on taxes especially when there is a change on tax directives. Furthermore awareness among taxpayers plays an important role on tax compliance. By having Lack of awareness, most of taxpayers do not pay their taxes timely and as a result they pay with penalty. Lastly the result revealed that in order to increase tax compliance level the government educating the taxpayers and conducting consultation sessions, Improving relationship with the Public and Providing necessary information to taxpayers

\section{CHAPTER 5 CONCLUSION AND RECOMMENDATION}

\section{Conclusion}

Tax compliance is very crucial in promoting the economic growth of any country. A strategy to increase the level of compliance should begin with understanding what the factors that affect the compliance level taxpayers are. The major objective of this study is to examine the determinants of voluntary tax compliance behavior of category A and B tax payers in Case of Dire Dawa City Administration. The results of ordered logistic regression results show that tax compliance is affected by broad range of factors such as Demographic, Individual, Social, Institutional and Economic factors.

Tax knowledge is a corner stone as far as voluntary compliance is concerned. Tax attitudes can be improved through better tax knowledge' this will in turn increase compliance and reduce the inclination to evade taxes. Thus, higher knowledge regarding taxes leads to higher compliance, while poor knowledge leads to higher noncompliance. Similarly complexities of tax System have negative and significant relation with the level of compliance. Therefore, increasing taxpayers' knowledge by simplification of tax law can have a positive contribution for the level of compliance. Beside, Government spending on the social and welfare needs of its citizens has positive and significant influence on tax compliance behavior of tax payers. In related with this Role of the Tax Authority maintain an aggressive attitude with respect to the correctness of the taxpayers' actions will build positive attitude on the tax payers and this attitudes will contribute to trust in authorities and consequently will enhance voluntary tax compliance of the tax payers.

The study has also found absence of fairness and absence of audit has negative and significant relationship with tax compliance of the tax system. If the tax system is not based on the ability- to pay principles or if it is unfair, it has a negative consequence on the compliance level of the tax payers. This implies that making the tax 
system fair leads to higher levels of tax compliance behavior of the taxpayers. Similarly, the result of the study reviled that a high probability of audit or detected encourages taxpayers to be more compliant. As level of compliance influenced by the frequency of the authority's tax audit activities, the tax authorities and the concerned bodies should pay due attention.

Tax authority is the responsible body for assessing and collecting the city's tax revenue. The amount of revenue collected is directly dependent on the efficiency and effectiveness of the authority. However, the study revealed that there is lack of sufficient personals in the authority. With insufficient staff, tax authorities cannot improve voluntary tax payers' compliance and there by tax revenues.

In general, the findings from the regression analysis indicate that, compliance is significantly affected by nine determinant factors which consist of: Age, Education, Tax knowledge, Financial Constraints, Absence of Fairness, and Role of the Tax Authority, complexity of Tax System, Absence of Tax Audits and Government Spending. This study also evidenced that, other variables such as Gender, Sales turn over, Religion, Penalties, Type of organization and Tax Rate were not significant determinants of tax compliance id Dire Dawa City Administration.

\section{Recommendation}

$>$ Though the study found that education has inverse relation with the level of compliance, the government should make a strategy to increase the tax knowledge since tax knowledge positively affect the level of compliance.

$>$ As complex tax system decrease the level of compliance, the tax system of the country should be simplified, if there is any changes in tax legislation it should be communicated to citizens in their native languages for effective and efficient tax administration as well as in order to improve tax compliance.

$>$ As absence of audit decrease the level of compliance, there should be Continues and frequent audit standard and procedures to increases compliance as well as to curb the deadweight loss of the economy.

$>$ As penalty is insignificant factor, It is advisable to have an incentive mechanism for those tax payer there level of compliance is high.

$>$ Even though, the study found that tax rate is insignificant factor in this study, the tax authority should work on reducing the levels of tax burden by increasing the tax base in order to increase both voluntary compliance and general tax revenues.

$>$ To reduce the level of non compliance, in addition to examining books of account, auditors should visiting taxpayers' business premises hence facilitates the detection of cases where tax evasion or avoidance is involved.

$>$ Giving training and educating the taxpayers

$>$ The tax authority should Automation of the tax system and should be integrated and consolidated with other macroeconomic reforms by introduces new mechanism for Probability of detection.

$>$ Taxpayers, especially those in high tax brackets are sensitive to governments spending. Therefore, the government should use the taxpayers' money wisely and in a transparent manner and communicate with the taxpayers about tax programs to promote the benefits of paying taxes.

$>$ The findings suggest that if the tax systems treat equal people in equal circumstances in an equal way and by ensuring tax fairness and equity voluntary compliance behavior can be developed.

$>$ Finally, Tax compliance will be developed just with the voluntary cooperation of the society with the tax authority. To improve general tax compliance level as well as total tax revenue the government should do everything possible to increase public knowledge on tax matters and tax education should be included in education system of the country at different level. The government should create healthy relationship between those that raise taxes and those that spend taxes creates positive synergy for compliance.

\section{Further study}

The findings of this study are only focus on category A and category B tax payer in Dire Dawa City Administration. Consequently, by having given the theoretical and empirical ambiguity on the factor affecting compliance, if further study is made at regional and national level by incorporating more variables in to the model that are expected to affect voluntary compliance behavior of taxpayers, the study can improved further. Last, empirical investigation of time series data on business tax payer's level of compliance will potentially uncover further, as yet unobserved factors that shape level of compliance.

\section{REFERENCES}

Adimassu, N. A., and Jerene, W. (2016). Determinants of Voluntary Tax Compliance Behavior in Self Assessment System : https://doi.org/10.21275/ART20163576

Aguolu,O. (2004) .Taxation and Tax Management in Nigeria, 3rd Edition, Enugu; Meridan Associates 
Abdixhiku, L. (2013). Determinants of Business Tax Evasion in Transition Economies, A Thesis Submitted In Partial Fulfillment of the Requirement For The Degree Of Doctor Of Philosophy, Staffordshire University.

Akalu, K. (2016). Determinants of tax compliance behavior of large corporate taxpayers in Ethiopia, Msc Research Paper, Addis Ababa University, Addis Ababa, Ethiopia.

Allingham, M.G. and Sandmo, A. (1972). Income Tax Evasion: A Theoretical Analysis, Journal of Public Economics, https://doi.org/10.1016/0047-2727(72)90010-2

Ameyaw, B., and Dzaka, D. (2016). Determinants of Tax Evasion: Empirical Evidence from Ghana. Modern Economy, 7, 1653-1664.http://dx.doi.org/10.4236/me.2016.714145

Amina, A., and Saniya, K. (2015). Tax Compliance And Its Determinant The Case Of Jimma Zone , International Journal Of Research In Social Sciences, Vol. 6, No.2.

Kasipillai, J., \& Abdul H. (2006). Gender and Ethnicity Differences In Tax Compliance, Asian Academy of Management Journal, Vol. 11, No. 2, 73-88

Andreoni, J, Erard, B., and Feinstein, J. (1998). Tax compliance. Journal of Economic

Barbuta, N. (2011). A Review of Factors for Tax Compliance, ISSN 1584-0409

Becker ,GS. (1968). Crime and punishment: An economic approach. J. Pol. Econs., 76(2): 169-217.

Chung, J., and Trivedi, V.U. (2003). The effects of friendly persuasion and gender on tax compliance behavior, Journal of Business Ethics, Vol.47, p. 133-145.

Cummings, R.G. (2007). Effects of Tax Morale on Tax Compliance. Experimental and Survey Evidence

Daba, G. (2017). Factors Affecting Rental Income Tax Payers Compliance with Tax System: In Case of Hawassa City Administration, Research Journal of Finance and Accounting, Vol.8, No.7.

Dalu, T., Maposa, V.G., Pabwaungana, S., and Dalu, T. (2012). The impact of tax evasion and avoidance on the economy: a case of Harare, Zimbabwe, African Journal of Economic and Sustainable Development, Vol. 1, No. 3, pp.284-296.

Desta, K. (2010). Assessment of Taxpayers' Voluntary Compliance With Taxation: A Case Of Mekelle City, Msc Research Paper, Tigray, Ethiopia.

Dinku, T., and Alamirew A. (2018). External Factors Affecting Voluntary Taxpayers Compliance: The Case of Amhara National Regional State Revenue Authorities, Journal of Business \& Financial Affairs: 322. doi: 10.4172/2167-0234.1000322

Drummond, P., W. Daal, N. Srivastava \& L. E. Oliveira 2012. Mobilizing revenue in sub-Saharan Africa: empicial norms and key determinants. IMF Working Paper WP/12/108. Washington DC.: International Monetary Fund.

Dubin, A. (2004). Criminal investigation enforcement activities and taxpayer non-compliance. Paper presented at 2004 IRS Research Conference, Washington.

Eshag E (1983). Fiscal and monetary policies and problems in development countries. Cambridge: Cambridge University Press.

Ezana, G. (2018). Determinants of Tax Compliance: A Case Study on Nifas Silk Lafto Sub City Category "A" Tax Payers, Mekelle University, Mekelle, Ethiopia.

Federal Democratic Republic of Ethiopia. (2016). Growth and Transformation Plan II (GTP II) (2015/162019/20). https://europa.eu/capacity4dev/resilience_ethiopia/document/growth-and-transformation-plan-iigtp-ii-201516-201920

Fjeldstad, A.,\& Sjursen,(2010). Factors affecting tax compliant attitude in Africa: Evidence from Kenya, Tanzania, Uganda and South Africa :Chr.Michelsen Insitute Bergen, Norway

Hasseldine, J., and Hite, P. (2003). Framing, gender and tax compliance, Journal of Economic Psychology, Vol. 24, pp. 517-533.

Olugoke, A., \& Obazee, U. (2016). Tax Knowledge, Penalties and Tax Compliance In Small and Medium Scale Enterprises In Nigeria, Scientific Research Publishing, Http://Dx.Doi.Org/10.4236/Ib.2016.81001

Prince, K., and Obi, J.(2014). Impact of Tax Audit on Tax Compliance in Nigeria, International Journal of Business and Social Science, Vol. 5, No. 9.

IMF 2011. Revenue mobilization in developing countries. Policy Paper prepared by the Fiscal Affairs Department (8 March). Washington D.C.: International Monetary Fund.

Jackson, B., and Jaouen. (1989). Influencing taxpayer compliance through sanction threat or appeals to conscience, Advances in Taxation. Vol. 2, pp. 131-147.

Jacob, F. (2014). An Empirical Study of Tax Evasion and Tax Avoidance: A Critical Issue in Nigeria Economic Development, Journal of Economics and Sustainable Development, Vol.5, No.18.

Johns, A., and Slemrod, J. (2008). The Distribution of Income Tax Noncompliance, http://www.bus.umich.edu/otpr/DITN\%20091308.pdf

John, D. (2016). The Ultimate Guide to Writing a Dissertation in Business Studies: A Step-by-Step Assistance (1st ED). Research-methodology.net, publisher.

Kanbiro, K. (2018). Factors Influencing Taxpayers' Voluntary Compliance Attitude with Tax System: Evidence 
from Gedeo Zone of Southern Ethiopia, Universal Journal of Accounting and Finance, 92-107 http://www.hrpub.org DOI: 10.13189/ujaf.2018.060302

Kato, S. (2002). A study of research method. Faculty of business administration, Bunkyo Gakuin University, Japan.

Kirchler, E. (2007). The Economic Psychology of Tax Behaviour. Cambridge University Press.

Kirchler, E., Hoelzl, E., and Wahl, I. (2008). Enforced versus voluntary compliance: The "slippery slope" framework, Journal of Economic Psychology, 29, 210-55.

Lemessa, T. (2007). Determinants of Taxpayers' Voluntary Compliance with Taxation: The Case Study of Dire Dawa City, Msc Research Paper, Addis Ababa University, Addis Ababa, Ethiopia.

Manchilot, M. (2018). Determinants of Tax Compliance: A Case of Gondar City, Research Journal of Finance and Accounting, Vol.9, No.13.

Mamo, T. (2017). Tax fairness, tax knowledge and tax complexity of Bole sub city category "B" business profit taxpayers, Msc Research Paper, St. Mary's University, Addis Ababa, Ethiopia.

Mohani, A. (2001). Personal income tax non-compliance in Malaysia, PhD thesis. Victoria University, Melbourne, Australia.

Rizal, M., \& Fariq, A. (2011). Factors Affecting Tax Compliance Behavior In Self Assessment System, African Journal Of Business Vol. 5, No. 33, Pp . 12864-12872.

Rizal, M., Marissa, M., and Rahim, A. (2016). Issues, Challenges and Problems with Tax Evasion: The Institutional Factors Approach, GadjahMada International Journal of Business, Vol. 18, No. 2.

Song, Y.D., and Yarbrough, T.E. (1978). Tax ethics and taxpayer attitudes: A survey. Public Administration Review, 38(5), 442-452.

Swarnathilaka, D., and Kevin, L. (2017). Exploring Key Determinants of Tax Compliance Decision Among Individual Taxpayers in Sri Lanka, European Journal of Business and Management, Vol. 9, No.3.

Helhel, Y., \& Ahmed, Y. (2014). Factors Affecting Tax Attitudes and Tax Compliance: A Survey Study in Yemen, European Journal of Business and Management, Vol.6, No.22.

Inasius, F. (2018). Factors Influencing SME Tax Compliance: Evidence from Indonesia, International Journal of Public Administration, 10.1080/01900692.2018.1464578

Tadesse, G., and Goitom, A. (2014). Factors Influencing Taxpayers' Compliance with the Tax System: An empirical study in Mekelle City, eJournal of Tax Research, Vol. 12, No. 2, pp. 433-452.

Torgler, B. (2007). Tax Compliance and Tax Morale: A Theoretical and Empirical Analysis. Cheltenham: EE.

Worku, M. (2016). Assessment of Tax Evasion Case of Lideta Sub City Small Taxpayers Ethiopian Revenues and Customs Authority Branch Office, Msc Research Paper, St. Mary's University, Addis Ababa, Ethiopia.

World Bank Global Monitoring Report (2013). A joint publication of the World Bank and International Monitory Fund (C) 2013 international Bank for Reconstruction and Development 